Ann. Biol. anim. Bioch. Biophys., 1976, 16 (3), 345-348.

\title{
THE EFFECTS OF HANDLING ON EPISODIC RELEASE OF LH IN IMMATURE RATS
}

\author{
Pamela C. B. MacKINNON and Jeannine MATTOCK \\ Department of Human Anatomy, \\ University of Oxford
}

It has previously been found that during development immature female rats between 4-30 days of age and male rats from 6 days of age to adulthood occasionally show very high serum LH levels. Thus $\mathrm{r} 3 \mathrm{p}$. Ioo of female and $4 \mathrm{p}$. roo of male infant Wistar rats, which were killed by decapitation, had serum levels $>7.0 \mathrm{ng} \mathrm{NIH-}$ L/H-SI3/ml (MatTock and MacKinnon, 1975). To characterize the nature of these high $\mathrm{I}, \mathrm{H}$ levels groups of immature females (23-30 days of age) were serially bled by a number of different techniques with or without the use of anaesthesia (table I).

TABLE I

Serial blood sampling data obtained from groups of 23-30-day old female rats (Note the small number of LH samples $>7.0 \mathrm{ng} / \mathrm{ml}$ )

\begin{tabular}{|c|c|c|c|c|}
\hline & No. animals & Sampling times & $\begin{array}{l}\text { Total no. } \\
\text { samples }\end{array}$ & $\begin{array}{l}\text { Samples > } 7.0 \mathrm{ng} \\
\text { NIH-LH-S } 13 / \mathrm{ml}\end{array}$ \\
\hline Jug. vein cann. no anaesthetic .... & 8 & $20^{\prime} / 1 \mathrm{~h}$ & 48 & 0 \\
\hline Iliac vein cann. nembutal. . . . . . . & 5 & $5 / 1 \mathrm{~h}$ & 48 & 0 \\
\hline Tail bleeds no anaesthetic ....... & 6 & $10^{\prime} / 10^{\prime}$ & 21 & 0 \\
\hline Cardiac puncture ether .. & 8 & $15^{\prime} / 1 \mathrm{~h}$ & 32 & 0 \\
\hline Jugular vein ether ... & 21 & $10^{\prime} / 40^{\prime}-60^{\prime}$ & 111 & 8 \\
\hline
\end{tabular}

In the unanaesthetized animals which were bled either through an intra-atrial catheter or from the tail vein, or in anaesthetized groups bled through an iliac catheter or by cardiac puncture, only basal LH levels were found. However, 3 rats bled by jugular vein puncture under ether anaesthesia had high $\mathrm{LH}$ levels (fig. I), two of which showed peak levels of $\mathrm{LH}(>7.0 \mathrm{ng} / \mathrm{ml}$ ) which lasted for $20-30$ minutes. This 
apparent episodic release was unlike that of pulsatile $\mathrm{LH}$ release which is of smaller amplitude and greater frequency and has been observed in castrate rats of both sexes (GAY and SHETH, I972). Moreover, since episodic high LH levels were observed in both immature males and females and were not accompanied by increased prolactin levels (Matrock and MacKinnon, I975; see also fig. 2), they cannot easily be

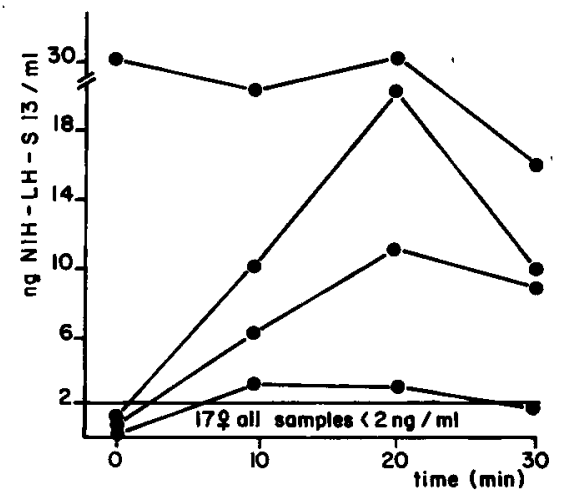

FIG. I. - LH levels (ng NIH-LH-Sr $3 / \mathrm{ml}$ ) abtained at 10 minute intervals by jugular vein puncture under ether anaesthesia in 23-30-day old female rats $(n=2 \mathrm{n})$

explained by a " positive feedback" response to an oestrogen stimulus. Nevertheless, episodic LH release was shown to be affected by " negative feedback " since the administration of a single dose of œstrogen ( $\mathrm{r} \mu \mathrm{g}$ ) 48 hours prior to decapitation suppressed high L,H levels.

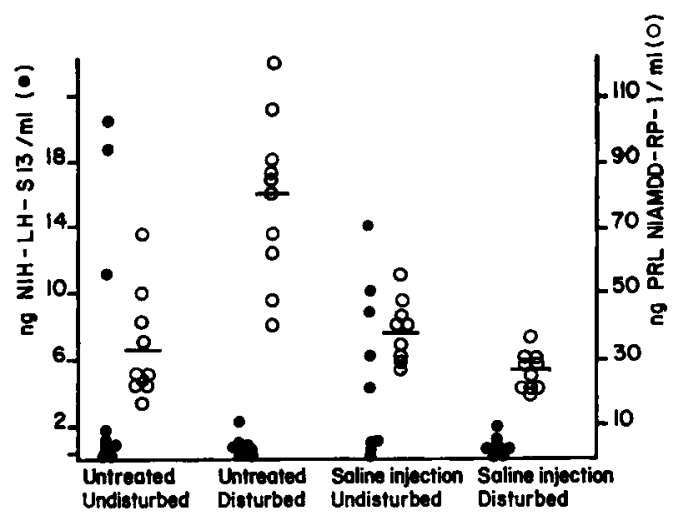

FIG. 2. - The effect of disturbance on $L H$ and $P R L$ levels in untreated females aged 23-30 days, and those given an injection of saline (Io Olgroup)

The unexpected paucity of high $L_{H} H$ values observed in the serially bled rats prompted an investigation of the effects of disturbance on $\mathrm{LH}$ release in the immature female (fig. 2). Groups of rats were left completely undisturbed for 24 hours or were given a single saline injection (but without further disturbance) 3 hours prior to 
decapitation. Other groups were similarly treated except that the animals were disturbed by transporting the cages to the laboratory about $30 \mathrm{~min}$. before decapitation. High LH levels were found in the " undisturbed " groups while only basal LH levels were found in the " disturbed " groups. It is notable that the effects of acute general disturbance could not be correlated with changes in prolactin levels, a finding which is contrary to reports on adult rats in which stress was observed to increase serum L,H and prolactin levels (AJrKa et al., I972).

Preliminary data not included here indicate that the inhibition of episodic $L_{1} H$ release is not mediated either by adrenaline or ACTH secretion since inhibition of high $L H$ values was still present in groups of adrenalectomized rats, and the presence of episodic release was observed in undisturbed rats treated either with ACTH or Dexamethasone. Administration of pentobarbitone (Nembutal, $0.3 \mathrm{mg} / \mathrm{xoo} \mathrm{g}$ body weight) 3 hours prior to decapitation was commensurate with episodic $L H$ release and therefore presumably prevented its inhibition. Although the possibility of a direct sympathetic effect on pituitary portal vessel blood flow has yet to be excluded, the evidence suggests that certain sensory stimuli transmitted via the central nervous system may lead to a suppression of high LH levels in immature animals.

Sexual Maturation 3rd Workshop August 31 September 3, 1975.

\section{ACKNOWLEDGEMENTS}

We wish to acknowledge Dr. G. D. Niswender who provided the antibody for an ovineovine radioimmunoassay; the National Institute of Health for NIH-LH-SI3 standard; the NIAMDD for the prolactin kit with NIAMDD-RP-I standard; and the Medical Research Council for financial support (grant No. G 973/922 B).

\section{RÉSUMÉ}

EFFET DE LA MANIPULATION DES ANIMAUX

SUR LES DÉCHARGES ÉPISODIQUES DE LH CHEZ LE RAT IMPUBÈRE

Chez le Rat immature, I3 p. Ioo des femelles et 4 p. Ioo des mâles présentent des taux de LH supérieurs à $7 \mathrm{ng} / \mathrm{ml}$ quand le sang est prélevé par décapitation.

Pour déterminer la nature de ces décharges de $\mathrm{LH}$, on a fait des prises de sang sériées à des Rattes de 23-30 jours avec ou sans anesthésie. Chez les animaux non anesthésiés et porteurs d'un cathéter intra-artériel et chez les animaux anesthésiés, on observe toujours un bas niveau de LH circulante.

D'autre part des animaux qui ne subissent aucune perturbation pendant 24 heures, décapités sur place (non stressés), ou après transport au laboratoire (stressés) présentent un taux de LH élevé en l'absence de stress et bas après le stress du transport.

Il semble que des stimulis sensoriels transmis par le système nerveux central peuvent provoquer une suppression des niveaux élevés de LH chez le Rat immature. 


\section{REFERENCES}

Ajika K, Kalra S. P., Fawcett C. D., Krulich L, McCanN S. M., r972. The effect of stress and newbutal on plasma levels of gonadotropins and prolactin in ovariectomized rats. Endocrinology, 90, 707-715.

GAY V. L., Sherh N. A., I972. Evidence for a periodic release of LH in castrated male and female rats. Endocrinology, 90, $158-162$.

Mattock J., Mackinnon P. C. B., Ter HaAr M. B., 1975. Serum gonadotrophin levels in male and female rats from birth to maturity. J. Findocr., 65, 2 P. (abstr.). 